\title{
SV40 early-to-late switch involves titration of cellular transcriptional repressors
}

\author{
Steven R. Wiley, ${ }^{1}$ Richard J. Kraus, Fengrong Zuo, Elizabeth E. Murray, ${ }^{2}$ Karla Loritz, and \\ Janet E. Mertz ${ }^{3}$
}

McArdle Laboratory for Cancer Research, University of Wisconsin, Madison, Wisconsin 53706 USA

\begin{abstract}
We have purified factors from HeLa cell nuclear extracts that bind to the transcriptional initiation site of the SV40 major late promoter (SV40-MLP). The resulting fraction consists predominantly of three proteins, collectively called initiator-binding protein of SV40 (IBP-s) with electrophoretic mobilities of $\sim 45-55 \mathrm{kD}$. Gel mobility-shift and DNase I-protection analyses indicate that each of these three proteins associates with high affinity to sequences located at the initiation site and 55 bp downstream of it. IBP-s-binding sites with lower affinities are located at +5 and +30 . Addition of purified IBP-s to a cell-free transcription system represses transcription from the SV40-MLP, but not the SV40 early promoter. SV40 mutants lacking the two strongest IBP-s-binding sites (1) are not repressed by the addition of IBP-s in vitro, (2) overproduce late RNA (relative to wild-type SV40) at low, but not high, template copy number in vitro, and (3) exhibit increased levels of late RNA at early, but not late, times after transfection into CV-1 cells. Therefore, IBP-s is a cellular repressor of transcription of the SV40-MLP that may, in large part, be responsible for the replication-dependent component of the early-to-late shift in SV40 gene expression. Partial amino acid sequence data obtained from the $\sim 55-\mathrm{kD}$ component of IBP-s indicate that it is hERR1, an orphan member of the steroid-thyroid hormone receptor superfamily. These findings suggest simple molecular mechanisms by which hormones may modulate expression of viral late genes. We speculate that activation of expression of the late genes of other viruses may occur by similar mechanisms.
\end{abstract}

[Key Words: HeLa cell nuclear extract; initiator binding protein of SV40; replication-dependent transcription; steroid-thyroid hormone receptor superfamily; SV40 major late promoter]

Received May 13, 1993; revised version accepted August 16, 1993.

Simian virus 40 (SV40) is a mammalian DNA tumor virus with a $5.2-\mathrm{kbp}$ double-stranded DNA genome (for review, see Tooze 1981). The genome contains two transcriptional units: the early one, expressed both in transformed cells and throughout the lytic cycle of infection of monkey cells; and the late one, expressed only after viral DNA replication has started (for review, see Tooze 1981). The promoters for these units direct initiation of transcription in opposite directions from a shared origincontrol region. This region also contains the origin of viral DNA replication, six Spl-binding sites, and the 72 bp repeat region with numerous transcriptional enhancers (Faisst and Meyer 1992).

Essentially all of the viral transcripts synthesized at early times after transfection or infection of African green monkey kidney cells initiate from the early promoter. On the other hand, most of the viral transcripts synthesized at late times (e.g., $40 \mathrm{hr}$ postinfection) initiate from the late promoter (Reed et al. 1976).

The molecular mechanisms of this early-to-late shift

Present addresses: 'Immunex Corporation, Seattle, Washington 98101 USA; ${ }^{2}$ Promega Corporation, Madison, Wisconsin 53711 USA.

${ }^{3}$ Corresponding author. in SV40 transcription have been partially deciphered. After infection, the products of the early genes, large and small $\mathrm{T}$-antigen, gradually accumulate in cells. At a sufficient concentration, large $\mathrm{T}$-antigen binds to the early promoter, thereby repressing initiation of transcription at that location $\leqslant 10$-fold (Tjian 1981). At a somewhat higher concentration, large $\mathrm{T}$-antigen also binds to the palindromic sequence at the origin of viral DNA replication where it, together with small t-antigen, plays several roles in replication of the viral genome (for review, see Boroweic et al. 1990). Large T-antigen also transactivates transcription by enhancer-binding factors (Casaz et al. 1991; Gruda and Alwine 1991; Xiao et al. 1991; Coulombe et al. 1992); however, as the latter mechanism activates the SV40 early and late promoters to similar levels and in a replication-independent manner (Wildeman 1989), it probably does not play a significant role in the early-to-late shift.

Transcription of the late transcriptional unit initiates at numerous sites throughout the origin-control region (Somasekhar and Mertz 1985 and references cited therein). However, $70-80 \%$ of the late transcripts initiate at SV40 nucleotide 325 (Good et al. 1988), which we refer to here as the SV40 major late promoter (SV40 
MLP). Genetic studies have identified three sequence elements, located at approximately $-30,+1$, and +30 relative to the site of initiation, which are required for efficient initiation of transcription at SV40 nucleotide 325 (Ayer and Dynan 1988 and references cited therein). The -30 region element functions as a binding site for the general transcription factor TFIID despite lack of a consensus TATA box sequence (Brady et al. 1982; Wiley et al. 1992). The +30 region element binds a cellular factor, downstream activator protein (DAP) (Ayer and Dynan 1990|.

Many promoters contain genetically important sequences at their sites of transcription initiation. These sequences are often referred to as initiator sequences. Here, we describe the purification and partial characterization of cellular factors that bind the initiation site of the SV40-MLP. Collectively, we call these factors IBP-s for initiator-binding protein of SV40. We show that they are transcriptional repressors of the SV40-MLP; however, their ability to repress is titrated out when the viral template copy number is high. Data presented in this paper support the conclusion that the binding of IBP-s to the SV40 late promoter is responsible for much, if not all, of the replication-dependent component of the early-tolate shift in expression of the SV40 genome.

\section{Results}

IBP-s binds at multiple sites in the -5 through +55 region of the SV4O-MLP

We used a DNase I protection assay to identify activities in HeLa cell nuclear extracts that bind specifically to the genetically important initiation site of the SV40-MLP. A factor consisting primarily of three proteins that bind to the SV40-MLP - 5 region, collectively called IBP-S, was purified to $>50 \%$ homogeneity by either of two multistep purification procedures. Method 1 included use of affinity chromatography with a 20-bp oligonucleotide identical in sequence to SV40 nucleotide 317-336, the sequence surrounding the SV40 major late initiation site at nucleotide 325 (see Materials and methods). In the absence of competitor DNA, this preparation of IBP-s protected from cleavage by either methidiumpropylEDTA-iron (MPE) or DNase I a region of the SV40-MLP from -7 through +65 relative to the initiation site (Fig. lA; summarized in Fig. 1B|. Although the affinity column used in this purification contained only the -8 through +11 region of the SV40-MLP, the resulting preparation of IBP-s protected most of this larger region because of the presence of multiple IBP-s-binding sites on the SV40-MLP (see below).

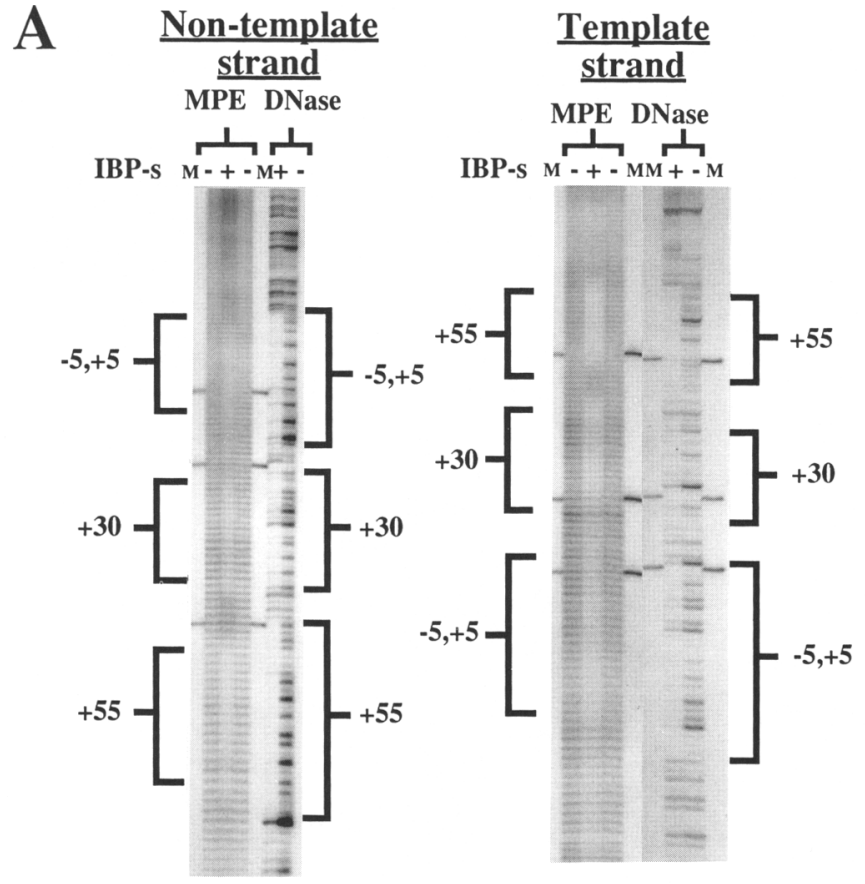

B Major Late
Initiation Site

5'-CCTCTTTCAG AGGTTATTTC AGGCCATGGT GCTGCGCEGG

GG CTGTCACGCC AGGCCTCCGT TAAGGTCGT AGGTCATGGA TCGCGGC GACAGTGCGG TCCGGAGGCA ATICCAAGCA TCCAGTACCT

^310

^320 $\wedge 340$ $\wedge 350$ $\wedge 360$

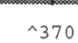

^370
Figure 1. Regions of the SV40-MLP protected by IBP-s from cleavage with DNase I and MPE. $\{A \mid$ Footprints of IBP-s on the SV40-MLP. The $3^{\prime}$ end-labeled probes were incubated with $(+)$ or without $(-)$ purified fractions of IBP-s $\mid \sim 20 \mathrm{ng}$ of IBP-s prepared by method 1) and cleaved with either DNase I or MPE as indicated. Marker lanes contained aliquots of probe cut separately with NcoI, HpaII, and MseI and subsequently pooled before electrophoresis. The brackets indicate the protected regions, with the numbers specifying their approximate locations relative to the site of initiation. $(B)$ Summary of the IBP-s-protected regions. Outer stippled lines indicate regions protected from cleavage by DNase I; inner solid lines indicate regions protected from cleavage by MPE. Numbers along the bottom indicate SV40 nucleotide residues in the SV40 numbering system (Tooze 1981). 
IBP-s from HeLa cell nuclear extracts consists predominantly of three proteins $45-55 \mathrm{kD}$ in size

A second, more efficient purification procedure for IBP-s involves the use of an oligonucleotide affinity column made with the initiator sequence of the SV40 mutant pm324C (see Materials and methods). This mutant differs from wild-type $S V 40$ by a $T \rightarrow C$ change at nucleotide 324. Its initiator sequence binds IBP-s with a higher affinity than does the wild-type SV40 initiator sequence (see below). Figure 2 shows a typical purification of IBP-s by this method. Analysis by SDS-PAGE of the proteins present at various stages during the purification indicated the enrichment for three proteins, $\sim 45-55 \mathrm{kD}$ in size, that together account for the majority of the protein present after the second oligonucleotide affinity purification step (Fig. 2B). These same three proteins also predominated when IBP-s was purified by method 1 with the wild-type SV40 initiator DNA affinity column (data not shown).

We determined which of the proteins present in the purified fraction bound the SV40 major late initiator by a gel mobility-shift experiment followed by SDS-PAGE (Fig. 3). The DNA probe used was synthesized by PCR from mutant pm324C. As a negative control, we used a probe made from mutant pm322C. This latter mutant contains a nucleotide $322 \mathrm{G} \rightarrow \mathrm{C}$ point mutation that significantly reduces binding of IBP-s to the -5 region (see below). As expected, IBP-s reduced the mobility of most of the probe made from pm324C but little of the probe made from pm $322 \mathrm{C}$ (Fig. 3A, cf. lane 2 with 3). The regions of the gel corresponding to the major shifted bands were excised from this nondenaturing gel. The proteins contained in them were resolved by SDS-PAGE and visualized by silver staining (Fig. 3B). The gel slice obtained with the high-affinity binding site probe contained high levels of all three of the $45-$ to $55-\mathrm{kD}$ proteins (Fig. 3B, cf. lane 2 with 1). On the other hand, the gel slice obtained with the low-affinity binding site probe contained only low, albeit enriched, amounts of these three proteins (Fig. 3B, lane 3). The $110-\mathrm{kD}$ protein present at similar levels in lanes 2,3 , and $L$ of Figure $3 B$ is probably a nonspecific DNA- or Sepharose-binding protein. We conclude that all three of the major proteins present in the highly purified fractions of IBP-s are responsible for the SV40-MLP initiator-binding activity.

To further demonstrate that IBP-s binds specifically to the initiator of the SV40-MLP, we also identified the DNA sequences in the probe/IBP-s complex that were protected from DNase I cleavage. After incubation with IBP-s of end-labeled probes similar to those used in Figure 3, DNase I was added to the mixture $60 \mathrm{sec}$ before electrophoresis as in Figure 3A. The population of probe with electrophoretic mobilities that were slowed by binding of IBP-s was protected from DNase I cleavage over the SV40 major late initiation site (Wiley 1993). Therefore, IBP-s binds specifically to this region of SV40 DNA.

A slower migrating band of the gel-shifted probe was also seen reproducibly (e.g., Fig. 3A; Wiley 1993). Analysis of this material indicated protection from DNase I cleavage over the +5 and +30 regions as well as the -5 region (data not shown). Quite likely, this material consists of IBP-s bound concurrently to more than one site per DNA molecule.

\begin{tabular}{|c|c|c|c|}
\hline \multicolumn{4}{|c|}{ Purification of IBP-s: Method 2} \\
\hline Step & $\begin{array}{c}\text { Total } \\
\text { protein }(\mathrm{mg})\end{array}$ & Activity & $\begin{array}{l}\text { Fold } \\
\text { purif. }\end{array}$ \\
\hline Crude extract & 25,000 & nd & 1 \\
\hline DEAE & 22,000 & nd & 1 \\
\hline Heparin & 40 & 6,000 & 60 \\
\hline Oligo $1^{\text {st }}$ pass & 0.1 & 4,000 & 25,000 \\
\hline Oligo $2^{\text {nd }}$ pass & 0.06 & $3, \mathbf{5 0 0}$ & 38,000 \\
\hline
\end{tabular}

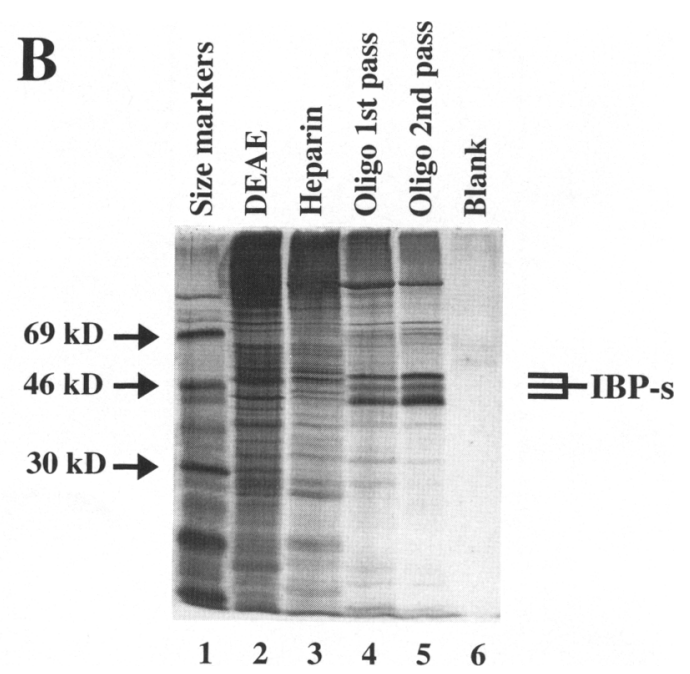

Figure 2. Purification of IBP-s. (A) Summary of a typical purification of IBP by method 2. Total protein amounts were calculated from $\mathrm{OD}$ at $280 \mathrm{~nm}$ or silver-stained SDS-PAGE. Activity was estimated by assaying the amount of protein required to achieve $50 \%$ protection of the +55 region from cleavage by DNase I. (nd) Not detectable. (B) Silver-stained SDS gel of fractions from a typical purification. Amounts of protein loaded per lane were as follows: (lane 1 ) $50 \mathrm{ng} /$ band of marker protein; (lane 2) $15 \mu \mathrm{g}$ of DEAESepharose flowthrough; (lane 3) $20 \mu \mathrm{g}$ of heparin-Sepharose $(325-750 \mathrm{~mm} \mathrm{KCl} \mathrm{step);} \mathrm{(lane} \mathrm{4)} 350 \mathrm{ng}$ of first-pass IBP-s pooled peak column fractions; (lane 5) $400 \mathrm{ng}$ of second-pass IBP-s column (250-650 mM KCl step); (lane 6) SDS loading buffer only. 


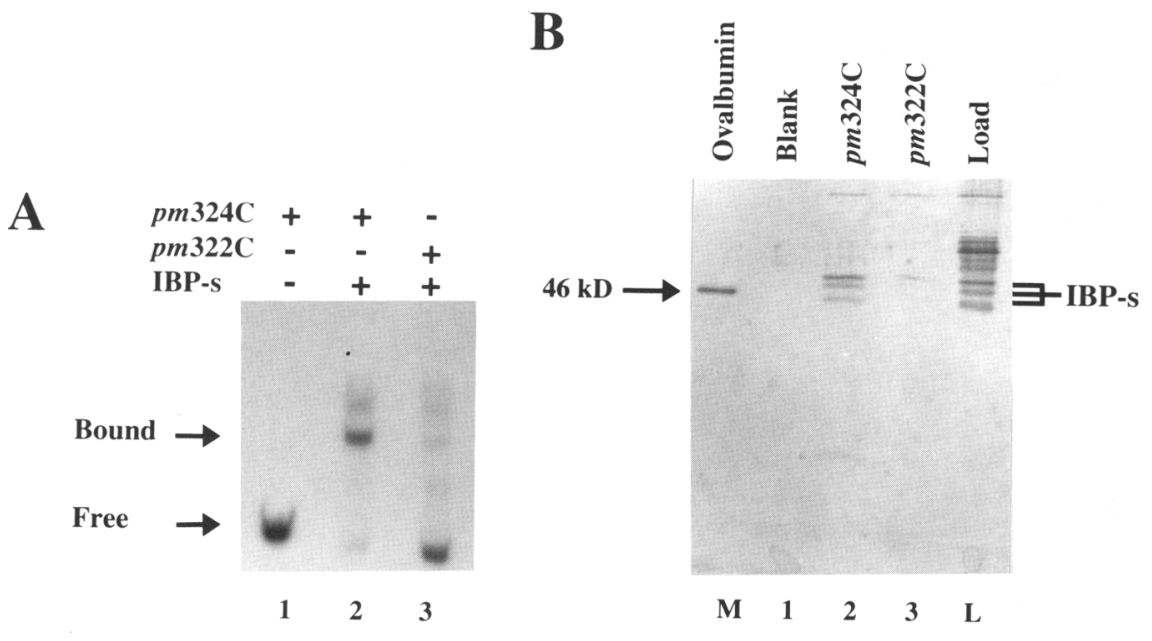

Figure 3. Three $\sim 45$ - to $55-\mathrm{kD}$ proteins contain IBP-s gel mobility-shift activity. (A) Preparative gel mobility-shift assay of IBP-s DNA-binding activity. All lanes contained $0.25 \mu \mathrm{g}$ of poly[d(I-C)]/poly[d(I-C)]. (Lane 1) Radiolabeled double-stranded probe (60 ng) of SV40 nucleotides 281-366 generated by PCR with mutant pm324C serving as template; (lane 2) same as lane 1 , but with the addition of $75 \mathrm{ng}$ of the 45to $55-\mathrm{kD}$ IBP-s proteins (as estimated by silver-stained SDS-PAGE); (lane 3) same as lane 2, but with probe generated from $\mathrm{mu}$ tant pm322C. (B) Silver-stained SDSPAGE of proteins contained in the "bound" bands from $A$. Gel slices excised from the native gel were resolved by SDSPAGE and visualized by silver staining. (Lane L) Loaded with $60 \mathrm{ng}$ of IBP-s; (lane M) loaded with $25 \mathrm{ng}$ of ovalbumin as size marker; (lanes 1,2, and 3) loaded with gel slices from the bound regions of $A$, lanes 1,2, and 3 , respectively.

\section{IBP-s binds with high affinity to sequences resembling 5'-AGGTCA-3'}

Competition gel mobility-shift assays were performed to determine the sequence specificity of IBP-s for various sequences (Fig. 4). The high-affinity binding site probe is the same one as in Figure 3. Different unlabeled, doublestranded oligonucleotides were used to reduce the amount of probe retarded in the presence of IBP-s (Fig.
4 C). The pm324C -5 region oligonucleotide competed three- to fourfold better than the corresponding wildtype oligonucleotide for binding of IBP-s (Fig. 4A, cf. lanes 5-8 with 9-12). On the other hand, the pm322C -5 region oligonucleotide failed to compete for binding of IBP-s even at high concentrations (Fig. 4A, lanes 1-4). Therefore, SV40 nucleotides 322 and 324 are part of the sequence recognized by IBP-s for binding in this region.

The IBP-s fraction also contains activities that protect
A
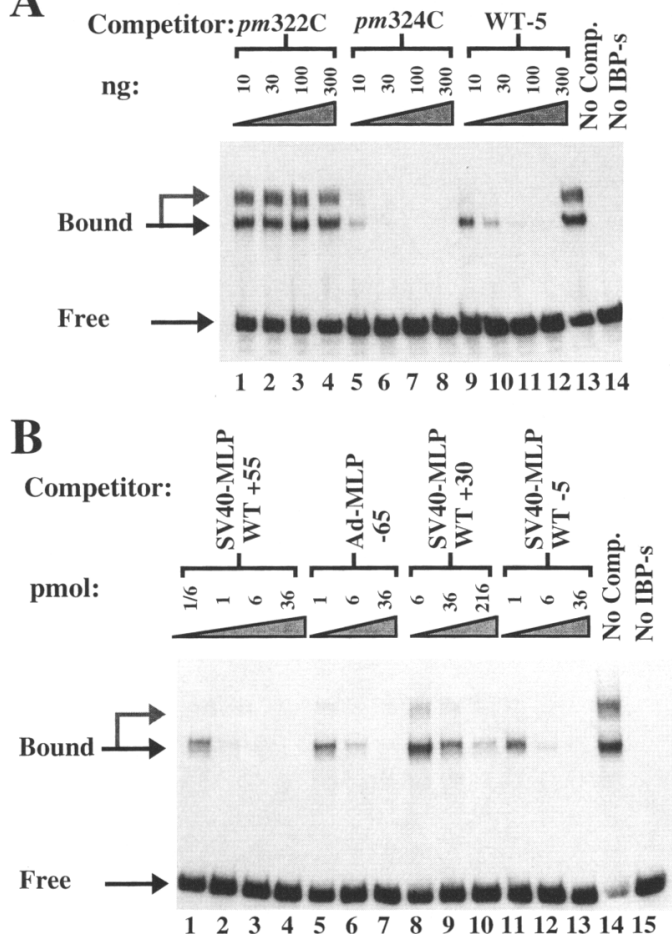

C

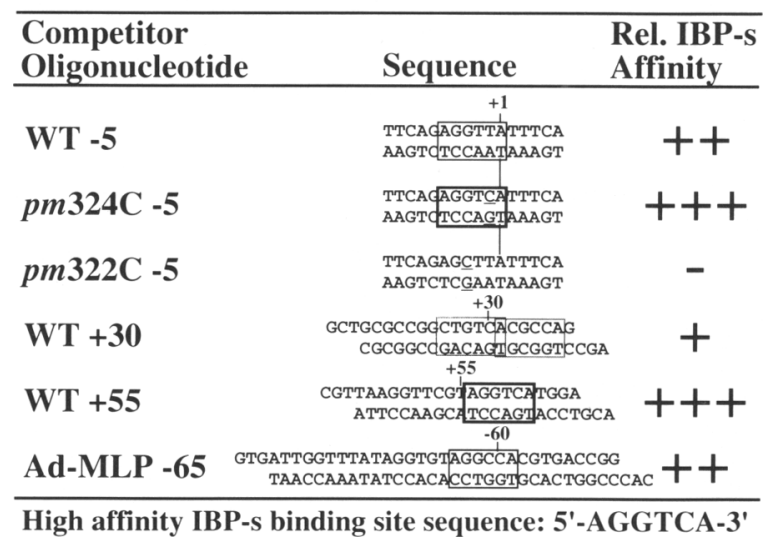

Figure 4. Relative affinities of IBP-s for a variety of sequences. $(A)$ Each reaction mixture contained $\sim 6$ fmoles of $5^{\prime}$ end-labeled, 86 bp of $S V 40$ nucleotides 281-366 (pm 324C) probe DNA, and 6 fmoles of IBP-s. The shaded wedge indicates the migration position of a weaker shifted signal thought to be the result of IBP-s-binding to more than one site on the probe. Double-stranded oligonucleotides ( $16 \mathrm{bp}$ ) corresponding to mutations in the IBP-s - 5-binding site were used as competitor ( $10 \mathrm{ng}=0.94$ pmole), the sequences of which are shown in $C_{\text {; }}$ amounts in each reaction are as indicated. $(B)$ Same as in $A$, but with competitor DNAs corresponding to other known IBP-s-binding sites. $(C)$ Summary of IBP-s-binding data shown in $A$ and $B$. The boxed sequences indicate the bases probably involved in IBP-s binding as determined by these and other mutational analyses (data not shown). The darkness of each box indicates the affinity of IBP-s for that site. The numbers indicate the position of the sequence relative to the start site of their respective promoters. 
from DNase I cleavage the +30 and +55 regions of the SV40-MLP (see Fig. 1) and a sequence 65-bp upstream of the initiation site of the adenovirus type 2 major late promoter (Ad-MLP) (data not shown). Competition gel mobility-shift assays were performed with oligonucleotides corresponding to these regions (Fig. 4C) to determine whether the factors in the IBP-s preparation responsible for these protected regions were the same as the ones responsible for protection over the SV40 major late initiator. The oligonucleotide corresponding to the +55 region of the SV40-MLP competed better than the wild-type -5 region oligonucleotide did (Fig. 4B, cf. lanes $1-4$ with 11-13), whereas the one corresponding to the +30 region competed approximately an order of magnitude less well (Fig. 4B, cf. lanes 8-10 with 11-13). The -65 region Ad-MLP oligonucleotide competed approximately as well as the -5 region oligonucleotide of wild-type SV40 (Fig. 4B, cf. lanes 5-7 with 11-13). Therefore, all of these regions contain one or more binding sites for IBP-s, albeit binding sites with varying affinities. A comparison of these sequences with their relative affinities for binding of IBP-s indicates that an optimal binding site probably resembles $5^{\prime}$-AGGTCA-3' (Fig. $4 \mathrm{C}$ ). Interestingly, this sequence matches the consensus half-site recognition sequence of many members of the steroid-thyroid hormone receptor superfamily (see Discussion).

\section{$I B P$-s can transcriptionally repress the SV40-MLP}

One method by which we examined the effect of IBP-s on transcription from the SV40-MLP was by addition of IBP-s to a cell-free transcription system derived from nuclear extracts of HeLa cells. The templates tested (all placed in a mutant XS13 background so that transcription would be activated efficiently by Spl) were wildtype SV40, mutant pm322C [defective in binding of IBP-s to the -5 region (Fig. 4)], mutant LS26 (Ayer and Dynan 1988) [defective in binding of IBP-s to the +55 region (Wiley 1993)], and the double mutant pm322C $\times$ LS26 (defective in IBP-s binding to both of these high-affinity sites). The addition of highly purified IBP-s decreased transcription from the wild-type SV40-MLP (Fig. 5, lanes 2-4) but not from the SV40-MLP double mutant (Fig. 5, lanes 11-13). The extent of repression correlated with the amount of IBP-s present in the reaction (Fig. 5, cf. lane 4 with lanes 3 and 2). When approximately equimolar amounts of SV40-MLP template and each species of IBP-s protein (as judged by silver-stained SDS-PAGE) were combined before addition of HeLa nuclear extract, transcription was repressed by $\sim 50 \%$. The templates with mutations in only one of the IBP-s binding-sites, pm322C and LS26, exhibited intermediate phenotypes, with higher concentrations of IBP-s needed for significant repression (Fig. 5, cf. lanes 5-7 and 8-10 with lanes 2-4; data not shown).

One caveat of this experiment is that transcription from the wild-type template is less than from the mutant templates even without the addition of purified IBP-s

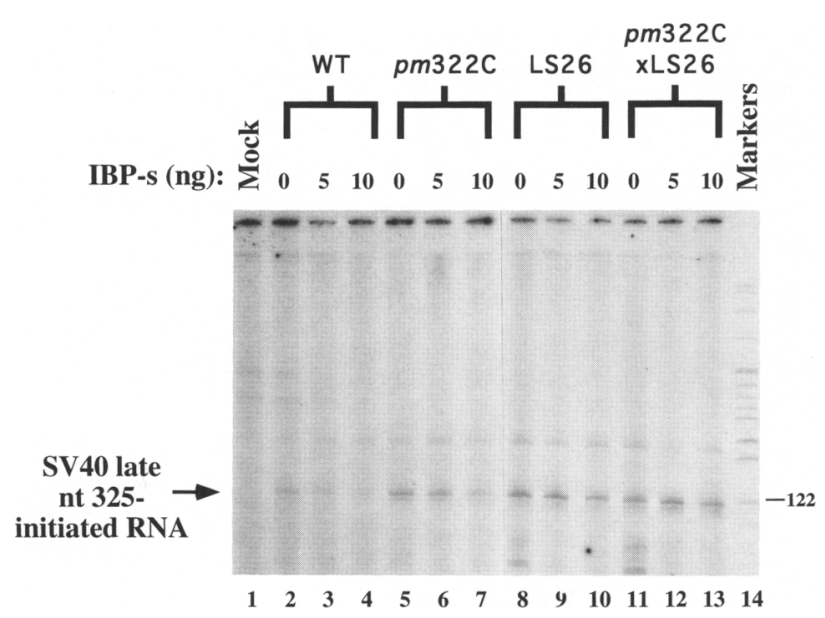

Figure 5. Addition of IBP-s to a cell-free transcription reaction represses SV40 late RNA synthesis by binding to the SV40MLP. Various amounts of purified IBP-s were incubated at $4^{\circ} \mathrm{C}$ for $10 \mathrm{~min}$, then for $15 \mathrm{~min}$ at $26^{\circ} \mathrm{C}$ with $100 \mathrm{ng}$ of wild-type SV40 and the indicated IBP-s binding-site mutants [all containing the XS13 deletion mutation of the 72 -bp repeat region as well (Fromm and Berg 1982)]. Afterward, $5 \mu \mathrm{l}$ of HeLa cell nuclear extract and NTPs were added and incubation was continued at $26^{\circ} \mathrm{C}$ for $30 \mathrm{~min}$ in a final reaction volume of $25 \mu 1$. Products were analyzed by primer extension and resolved by electrophoresis using a denaturing gel. The arrow indicates the location corresponding to transcripts initiated from the MLP. (Mock) No SV40 DNA included in the transcription reaction, (Markers) MspI-cut pBR322 DNA.

(Fig. 5, cf. lanes 2 with 5,8 , and 11 ). This finding is probably the result of some IBP-s being present in the nuclear extract itself. Nevertheless, these data indicate that IBP-s can transcriptionally repress the SV40-MLP, with the extent of repression being dependent on both the amount of IBP-s and the number of high-affinity IBP-s-binding sites present on the template.

To examine in further detail the effect of the template/ IBP-s ratio, we performed cell-free transcription reactions in which the template concentration was varied rather than the amount of IBP-s present in the extract. Representative data are shown in Figure 6A. At the lower concentration $(0.8 \mathrm{nmole})$, approximately one-fifth as much late RNA was synthesized from the wild-type template as from the double mutant (Fig. 6A, cf. lane 1 with 4). Once again, the mutants defective in one of the IBP-s-binding sites exhibited an intermediate phenotype (Fig. 6A, lanes 1-4). When normalized to the amount of SV40 early RNA synthesized concurrently from the SV40 early promoter present on these templates, the difference is even greater because of an underproduction of early message from the mutants (Fig. 6A, lanes $1^{\prime}-4^{\prime}$ ). This latter finding is probably the consequence of competition between the early and late promoters for transcription factors. On the other hand, at the higher template concentration (6.4 nmoles), no significant differences in late RNA synthesis were observed (Fig. 6A, lanes $7-10 \mid$. 

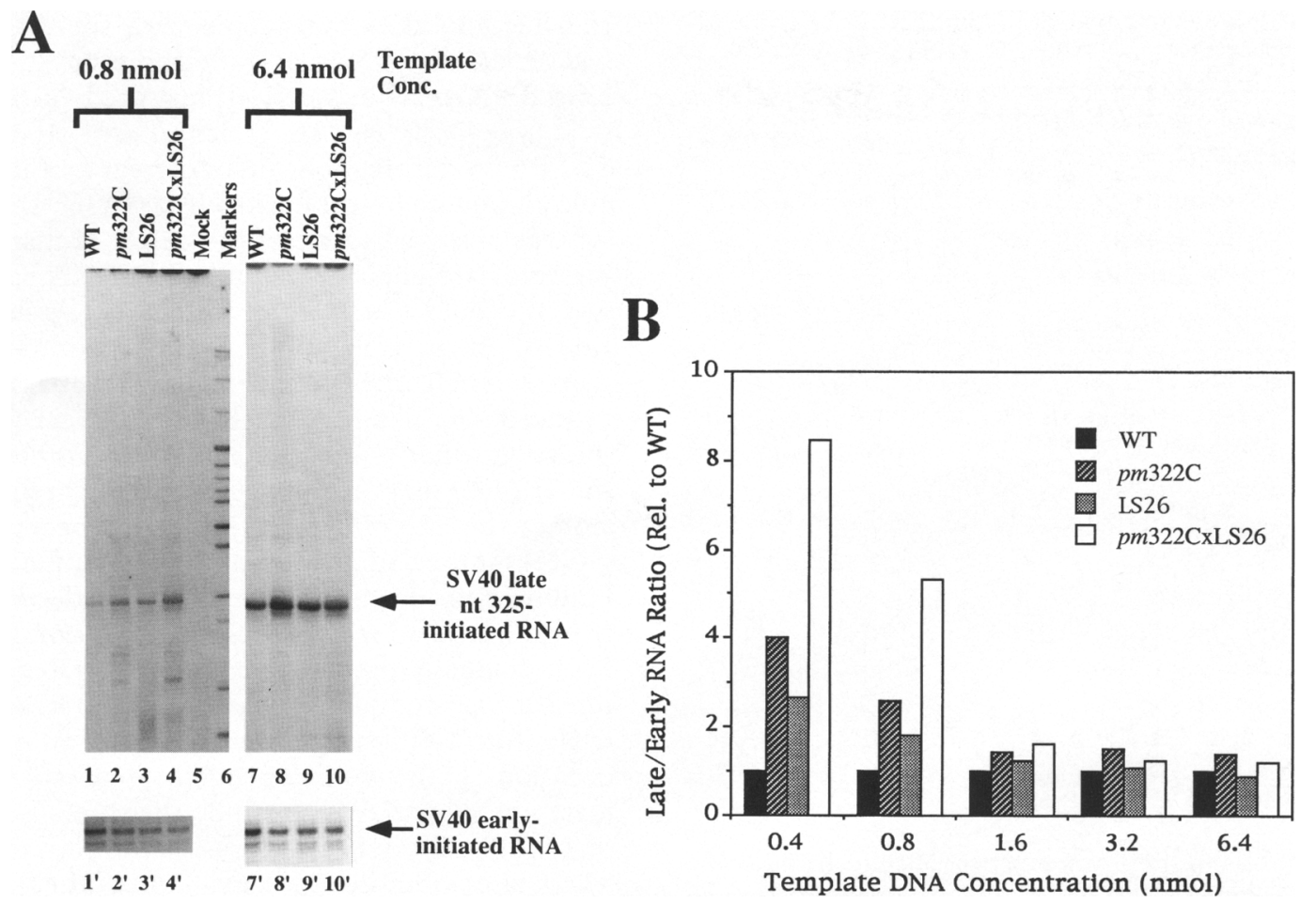

Figure 6. Binding of IBP-s to the SV40-MLP specifically represses SV40 late RNA synthesis at low, but not high, template concentrations. $(A)$ Primer extension analysis of the SV40 late RNA synthesized in a cell-free transcription system with wild-type SV40 and the indicated IBP-s-binding site mutants. Amounts shown of supercoiled plasmid DNA (in the XS13 background) were incubated for $30 \mathrm{~min}$ at $26^{\circ} \mathrm{C}$ in $50 \mu \mathrm{l}$ of HeLa nuclear extract transcription reactions. Half of each sample was analyzed by primer extension analysis for SV40 late RNA (lanes 1-5 and 7-10). Shown here is an autoradiograph of $7 \mathrm{~m}$ urea/10\% polyacrylamide gels in which the primer extension products were electrophoresed. The other half of each RNA sample was analyzed as above, but with an SV40 early RNA-specific primer (lanes $1^{\prime}-4^{\prime}$ and $\left.7^{\prime}-10^{\prime}\right)$. (Markers) BspI-cut pBR322 DNA. $(B)$ Effect of template concentration on repression of the SV40-MLP by IBP-s in a cell-free transcription system. An experiment similar to the one shown in $A$ was performed with wild-type SV40 and each of the IBP-s-binding site mutant DNAs indicated \{all in the XS13 background). Plotted here is the ratio of SV40 late nucleotide 325-initiated RNA/SV40 early-initiated RNA for each RNA sample relative to the ratio for the wild-type sample obtained from the transcription reaction performed in parallel at the same template concentration.

Figure 6B summarizes these and other data obtained from this experiment with several different template concentrations. Transcription from the SV40-MLP was found to be dependent on the ratio of IBP-s-binding sites/ IBP-s. At high ratios, where IBP-s was probably present in subsaturating amounts, the presence of IBP-s-binding sites had little, if any, effect on transcription from the SV40-MLP. However, at low ratios, the presence of the high-affinity IBP-s-binding sites was quite significant, with transcription from the wild-type SV40-MLP reduced to, at most, one-eighth of that observed with the double mutant templates. As expected, the single binding site mutant templates exhibited partially repressed phenotypes.

To test whether the effect of template concentration on transcription from the SV40-MLP is simply a consequence of titration of IBP-s by its binding sites, we examined the effect of the competitor oligonucleotides on transcription in vitro. The addition in trans of $0.5-1 \mu \mathrm{g}$ (50-100 pmoles) of pm324C -5 region oligonucleotide resulted in a 28 -fold increase in transcription from the wild-type SV40-MLP to a level similar to that ob- served with the double IBP-s-binding site mutant pm322C $\times$ LS26 (Fig. 7, cf. lanes 1-3 with 6 and 7). On the other hand, addition of this oligonucleotide increased transcription from the SV40-MLP of the double mutant only fourfold (Fig. 7, cf. lane 6 with 7). Most likely, this latter small increase is the consequence of relief of modest repression caused by IBP-s binding to the low-affinity sites at +5 and +30 . As a negative control, reactions were also performed in parallel with the pm322C -5 region oligonucleotide (see Fig. 4 C). As expected, addition of this oligonucleotide, which lacks IBP$s$-binding sites, had little effect on transcription from the wild-type SV40-MLP (Fig. 7, cf. lanes 4 and 5 with lane 1). Neither the pm322C nor the pm324C oligonucleotide affected synthesis of SV40 early RNA in these reactions (Fig. 7, lanes $1^{\prime}-5^{\prime}$ ). Therefore, IBP-s is a trans-acting factor that represses transcription specifically from the SV40-MLP by binding to cis-acting sequences located at and downstream of the initiation site of the SV40-MLP. At high template copy number or in the presence of an excess of IBP-s-binding sites supplied in trans, repression is relieved by titration. Furthermore, the 28 -fold increase 


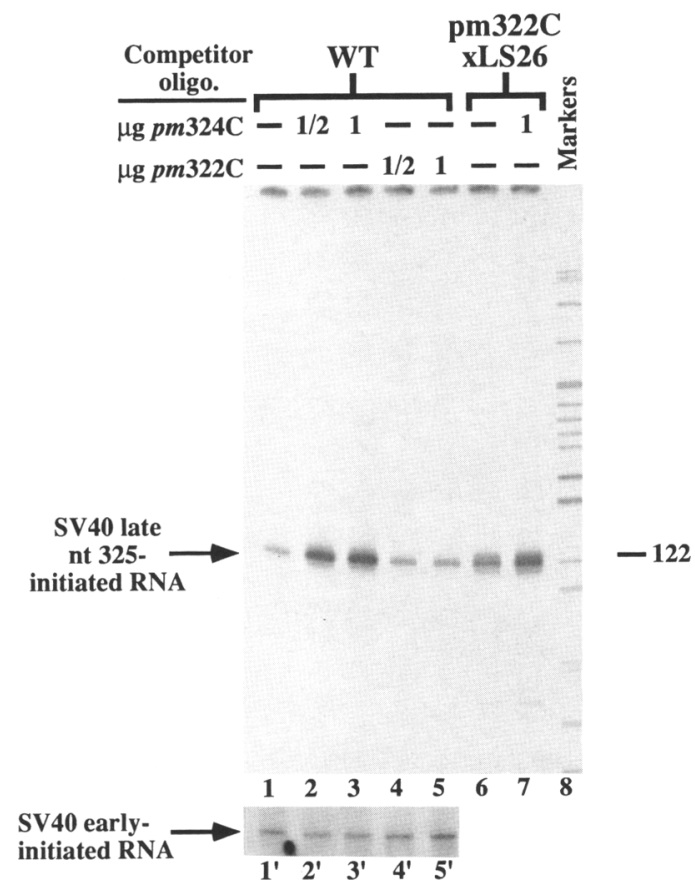

Figure 7. Addition in trans of competitor oligonucleotide containing an IBP-s-binding-site specifically relieves repression of SV40 late RNA synthesis in a cell-free transcription system. Supercoiled plasmid DNA (50 ng) containing wild-type SV40 (lanes 1-5) or the double IBP-s-binding site mutant pm322C $\times$ LS26 (lanes 6, 7) (both in the XS13 background) was incubated for $30 \mathrm{~min}$ at $26^{\circ} \mathrm{C}$ in $50 \mu \mathrm{l}$ of HeLa nuclear extract transcription reactions after addition of the indicated doublestranded oligonucleotides (sequences shown in Fig. 4C). The resulting SV40-specific RNAs were analyzed by primer extension as described in the legend to Fig. 6. (Markers) BspI-cut pBR322 DNA; (- | no competitor DNA.

in transcription observed upon the addition of the pm324C oligonucleotide indicates that the repression of the SV40-MLP by IBP-s might contribute quite significantly to the replication-dependent component of the early-to-late switch.

\section{$I B P$-s represses transcription from the SV40-MLP at early times after infection}

To determine whether these in vitro findings have relevance in vivo, we transfected in parallel into CV-1PD cells wild-type SV40 DNA and the three IBP-s-binding site mutants studied above. In this experiment, all promoters were placed in the genomic background of mutant SV1773(VP1-minus), so that packaging into virions would not occur. At various times after transfection, the cells were harvested and whole-cell RNA was purified. The relative amounts of the various spliced species of late and early promoter-specific RNAs present in each sample were determined by quantitative S1 nuclease mapping.

An example of some of the data obtained from one such experiment is shown in Figure 8A. By $18 \mathrm{hr}$ post- transfection, cells transfected with the double mutant had accumulated 9- to 11-fold more late promoter-specific RNA than had cells transfected in parallel with wild-type SV40 (Fig. 8A, cf. lane 1 with 4). However, by $38 \mathrm{hr}$ post-transfection, this difference in late RNA accumulation no longer existed (Fig. 8A, cf. lane 6 with 9). As was observed in vitro, the single mutants exhibited intermediate phenotypes and early RNA accumulation was affected little, if at all (Fig. 8A). The data obtained from all of the time points in this experiment are summarized in Figure 8B. These results are strikingly similar to those obtained in vitro (Fig. 6B). At early times after infection when viral template copy number was low, mutation of IBP-s-binding sites partially relieved repression of the late promoter. This relief of repression was greater for the double mutant than for either single IBP-sbinding site mutant. However, the difference between the mutants and wild-type SV40 in accumulation of late RNA gradually diminished with time after transfection until it was completely gone at late times in the lytic cycle. Similar findings were obtained on four separate occasions with two independent preparations of DNAs (data not shown). We conclude that the binding of IBP-s or an IBP-s-like activity represses transcription from the SV40 late promoter at early times after infection of SV40's natural host; this repression is relieved at late times, at least in part, by replication of SV40 DNA to high copy number titrating out the IBP-s present in the cell.

\section{Human estrogen-related receptor 1 is a major component of IBP-S}

To determine what proteins comprise the IBP-s activity, IBP-s was prepared according to method 2 /see Materials and methods), resolved in a standard $12 \%$ Laemmli sequencing gel, and blotted onto a polyvinylidene difluoride (PVDF) membrane. The slowest migrating of the three major protein components of IBP-s, the $\sim 55-\mathrm{kD}$ protein, was excised from the membrane and cleaved with endoproteinase Lys-C. The resulting peptides were separated by high-performance liquid chromatography (HPLC). One of these peptides was determined to begin with the sequence $(K) L V L S X L P K$, with $(K)$ being inferred from the cleavage specificity of Lys-C and the $\mathrm{X}$ representing an undetermined amino acid. The human estrogen-related receptor 1 (hERR 1$)$, an orphan member of the steroid-thyroid hormone receptor superfamily (Gigùere et al. 1988), is the only protein in the GenBank data base with this sequence. The molecular mass predicted from its amino acid sequence is $55.7 \mathrm{kD}$, in good agreement with the apparent size of this component of IBP-s. Furthermore, an antiserum raised against the COUP-TFs (Wang et al. 1989; kindly provided by M. Tsai), other orphan members of the steroid-thyroid hormone receptor superfamily (Wang et al. 1989), reacts by Western blot analysis with an $\sim 50-\mathrm{kD}$ protein present in our purified IBP-s (S. Johnston, unpubl.). However, as the COUP-TFs have significant sequence similarity with hERR1, it is not yet clear whether this antiserum cross-reacted with 

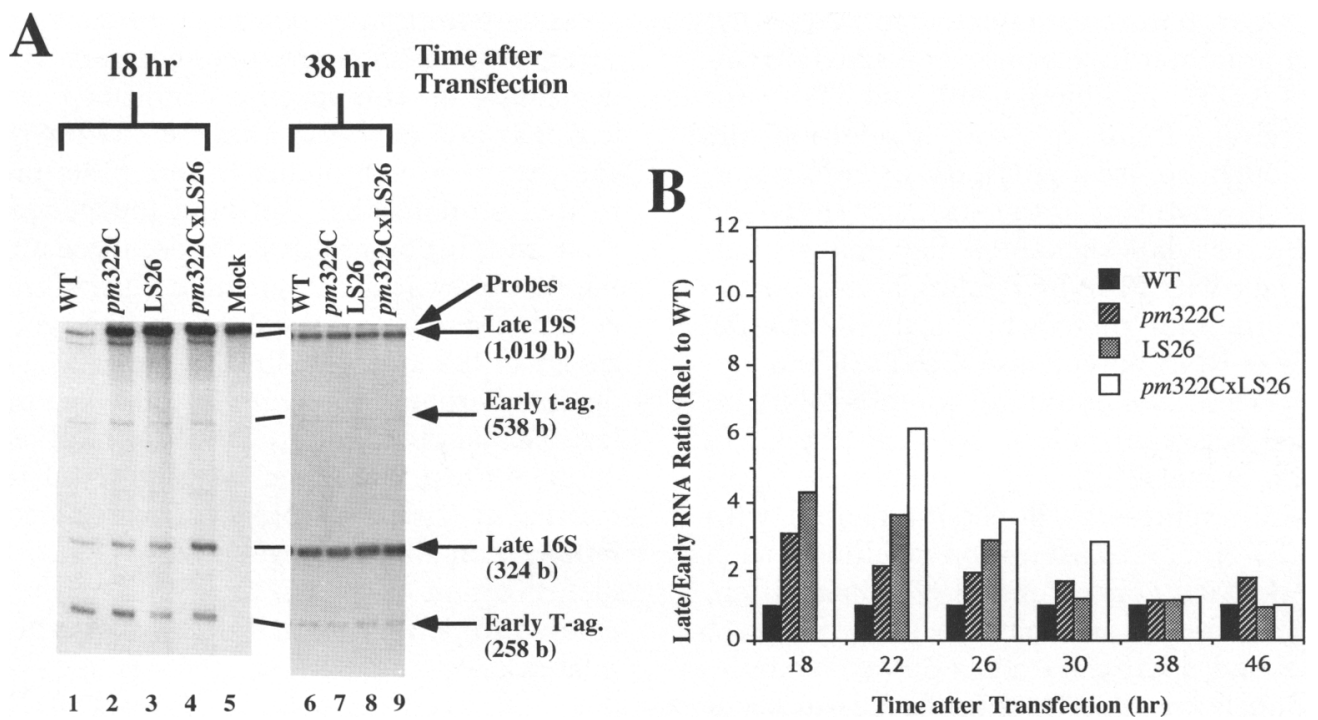

Figure 8. Binding of IBP-s to the SV40-MLP represses SV40 late RNA synthesis at early, but not late, times after transfection. (A) Quantitative S1 nuclease mapping analysis of SV40 early and late RNAs accumulated in CV-1PD cells $18 \mathrm{vs.} 38 \mathrm{hr}$ post-transfection with wild-type SV40 and the indicated IBP-s mutants. Whole-cell RNA was harvested at the times indicated. After purification, the relative amounts of SV40 early large T-antigen and late 16S mRNAs were determined for each sample by quantitative S1 nuclease mapping, with each hybridization reaction containing both early-and late-specific probes and $10 \%($ lanes $1-5)$ or $0.25 \%($ lanes $6-9)$ of the total RNA sample. The arrows at right indicate the DNAs protected by each of the SV40 mRNA species. (Mock) S1 nucleaseprotected DNA hybridized with RNA obtained from cells not receiving SV40 DNA. $(B)$ Effect of IBP-s-binding site mutations on accumulation of SV40 late RNA during the lytic cycle of infection. CV-1PD cells were transfected with wild-type SV40 and the IBP-s-binding site mutants indicated. At various times thereafter, whole-cell RNA was harvested and analyzed as in $A$. Plotted here is the ratio of SV40 late $16 \mathrm{~S}$ mRNA/SV40 early large T-antigen-encoding mRNA for each RNA sample relative to this ratio for the wild-type sample harvested at the same time after transfection. The relative wild-type ratios of late/early message were as follows: 18 $\mathrm{hr}, 1 ; 22 \mathrm{hr}, 5.3 ; 26 \mathrm{hr}, 21 ; 30 \mathrm{hr}, 70 ; 38 \mathrm{hr}, 133 ; 46 \mathrm{hr}, 157$. Southern blot analyses of the replicated viral DNA present in these samples indicated that the relative amount of wild-type DNA increased with time after transfection as follows: $18 \mathrm{hr}, 1 ; 22 \mathrm{hr}, 2.5 ; 26 \mathrm{hr}, 16$; $30 \mathrm{hr}, 55 ; 38 \mathrm{hr}, 169 ; 46 \mathrm{hr}, 244$. Also, the relative ratios of the wild-type/mutant DNAs at $18 \mathrm{hr}$ were as follows: wild-type, 1.0 ; pm322C, 0.85; LS26, 0.84; pm322C $\times$ LS26, 0.86 .

the $55-\mathrm{kD}$ protein, or whether COUP-TF1 or COUP-TF2 is another of the major protein components of IBP-s. Plasmids encoding COUP-TF1 and COUP-TF2 (a gift from $M$. Tsai) can reduce transcription specifically from the SV40-MLP when cotransfected into CV-1 cells (F. Zuo, unpubl.). Thus, members of the steroid-thyroid hormone receptor superfamily possess the attributes of IBP-s.

\section{Discussion}

We set out to identify cellular factors that induce transcription of the SV40-MLP by binding to the genetically identified sequence at the site of initiation. Instead, we found a set of proteins, collectively called IBP-s, that represses initiation of transcription by binding at and downstream of the site of initiation. As purified from HeLa cell nuclear extracts, IBP-s consists predominantly of three proteins, $\sim 45-55 \mathrm{kD}$ in size (Fig. $2 \mathrm{~B}$ ), each of which binds in a sequence-specific manner to the initiation site of the SV40-MLP (Fig. 3). The optimal sequence for binding of IBP-s appears to be 5'-AGGTCA-3' (Fig. 4). The partial amino acid sequence, apparent electrophoretic mobility, and sequence specificity are all consistent with the $55-\mathrm{kD}$ protein component being
hERRl, an orphan member of the steroid-thyroid hormone receptor superfamily. Interestingly, no function had been reported previously for this protein, although other members of this superfamily have been shown to act as transcriptional repressors under some conditions (Baniahmad et al. 1990; Cooney et al. 1992). IBP-s represses transcription from the SV40-MLP in vitro by sequence-specific binding to the template DNA (Fig. 5). This repression can be relieved by the addition in trans of IBP-s-binding sites (Fig. 7). The presence of these IBPs-binding sites is necessary for repression of the SV40 late promoter at early times in the lytic cycle of infection (Fig. 8). Preliminary order-of-addition single-cycle transcription experiments indicate that IBP-s represses transcription from the SV40-MLP before, but not after, formation of the transcription initiation complex (F. Zuo, unpubl.). We propose that IBP-s is a sequence-specific DNA-binding protein that represses transcription of the SV40 late promoter at early times after infection when template copy number is low; as viral template copy number (and the number of IBP-s-binding sites) increases during the course of the lytic cycle of infection, repression is relieved by replication-mediated titration of IBP-s. Thus, the SV40-MLP is free to be transcribed efficiently at late times after infection (Fig. 9). 
Assembly of the initiation complex on an RNA polymerase II-driven promoter involves several general transcription factors (GTFs) including TFIIB and TFIID (for review, see Zawel and Reinberg 1992). In addition, the SV40-MLP is thought to use a promoter-specific factor, DAP, that binds downstream of the start site (Ayer and Dynan 1990). We speculate that IBP-s may repress transcription from the SV40-MLP by binding at any of several sites on the promoter, thereby physically interfering with the binding of RNA polymerase II or DAP and preventing the proper protein-protein or protein-DNA interactions needed between these factors and the GTFs for the formation of stable initiation complexes. Alternatively, IBP-s may repress by direct interaction with components of the general transcription machinery such as TFIIB (Ing et al. 1992; Fondell et al. 1993). In addition, binding of IBP-s at the +55 site may block elongation of transcription beyond approximately +50 , a phenomenon noted previously by Aloni and colleagues to occur under some conditions (Hay et al. 1982 and references therein).

\section{Structure of IBP-S}

Three proteins, $\sim 45-55 \mathrm{kD}$ in size, were shown to bind specifically to the initiator region of the late promoter mutant pm324C (Fig. 3). One hypothesis to explain why these three proteins copurify by all procedures tested to date is that they exist as heteromeric complexes when bound to DNA. However, IBP-s-binding activity sediments in a glycerol gradient with an $S$ value corresponding to a globular protein with a molecular mass of $\sim 60$ $\mathrm{kD}$ (Wiley 1993). Therefore, these proteins probably exist as monomers in solution. However, these data do not eliminate the possibility that they form a heteromeric complex when bound to DNA. Some members of the steroid-thyroid hormone receptor superfamily can bind to DNA as monomers, heterodimers, or homodimers, depending on the specific conditions of the reactions (e.g., Lazar et al. 1991). Our preferred hypothesis is that the three major proteins in our IBP-s preparations are related proteins that can bind independently to DNA. First, the elution profiles of these three proteins are similar on the basis of salt gradient elution from a variety of columns (data not shown). Second, the gel mobility-shift assays of IBP-s exhibit linearity (e.g., Fig. 4). Third, data obtained from iron-hydroxyl-cleavage-mediated interference assays indicate that only a small region at the -5 or +55 sites is required for binding of IBP-s, which is consistent with the DNA being contacted by the DNAbinding domain of a single protein (Wiley 1993). Positive identification of the 45 - and $50-\mathrm{kD}$ proteins should enable us to determine definitively whether all three are related.

\section{Mechanism of binding of IBP-s}

At sufficiently high IBP-s/SV40-MLP ratios, most of the bases from -10 to +64 are protected from cleavage by DNase I and MPE (Fig. 1). One hypothesis to explain this finding is that IBP-s is a relatively nonspecific DNAbinding protein that can bind to a wide variety of sequences. Contrary to this hypothesis, IBP-s does not protect from DNase I cleavage sequences within $100 \mathrm{bp}$ of the initiation sites of the murine dihydrofolate reductase (DHFR) and the murine terminal deoxynucleotidyl transferase (TdT) promoters (data not shown). It also fails to protect promoter region sequences upstream of the -5 region of the SV40-MLP and downstream of the -65 region of the Ad-MLP (data not shown).

Another possibility is that IBP-s binds to weak sites on the SV40-MLP only by cooperative binding with the strong sites at -5 and +55 . This possibility was elimi-
Figure 9. Model for IBP-s repression of the SV40-MLP at early, but not late, times in the lytic cycle. At early times after infection, IBP-s blocks transcription by a mechanism dependent on IBP-s-binding sites being present near the major late start site. After sufficient replication of SV40 DNA has occurred, IBP-s no longer inhibits the binding of factors necessary for formation of an initiation complex, and transcription initiates at the SV40-MLP. The mechanism of release of IBP-s repression could be by titration of available IBP-s and/or other mechanisms (see Discussion). (GTFs) General transcription factors; (DAP) downstream activator protein (Ayer and Dynan 1990); (dark gray boxes) IBP-s-binding sites (this paper; Wiley 1993); (light gray boxes) essential recognition sites for factors involved in transcription from the SV40-MLP (Ayer and Dynan Mertz, in prep.; T. Eisenbraun, unpubl.).

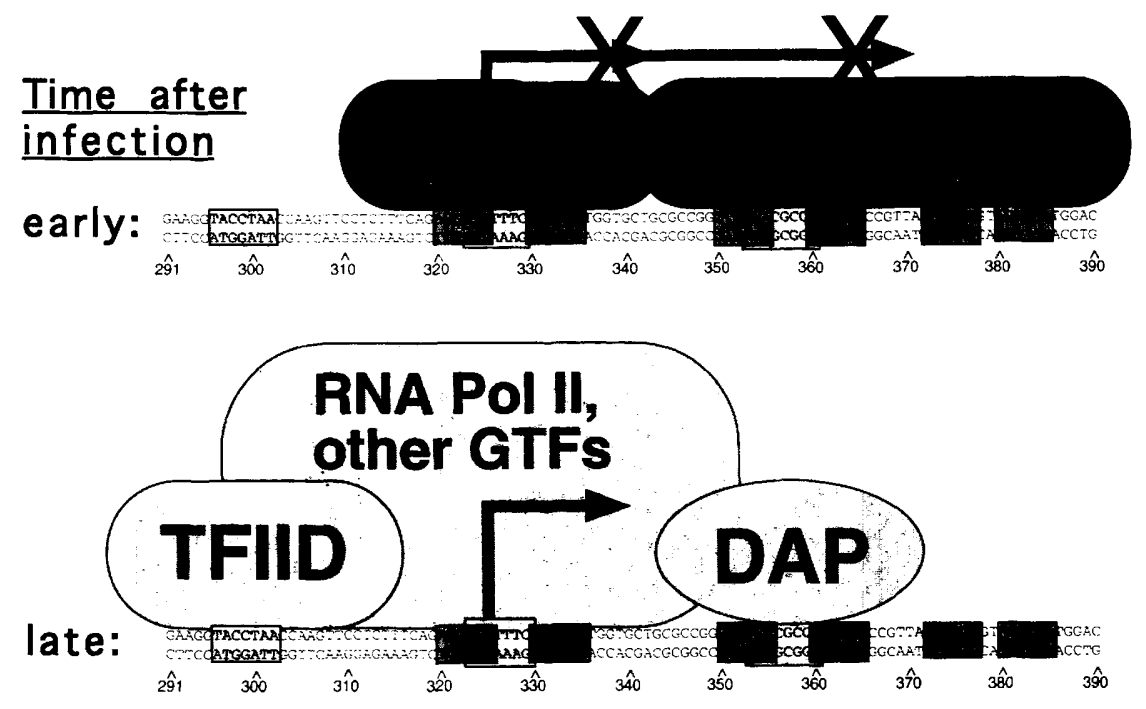

1988; Wiley et al. 1992; R.J. Kraus, E.E. Murray, S.R. Wiley, N.M. Zink, K. Loritz, and J.E. 
nated by the finding that IBP-s protects from DNase I cleavage its $+5,+30$, and +55 region-binding sites on mutant pm322C (data not shown). Similarly, the +55 region mutant LS26 is unaffected in its protection over the $-5,+5$ and +30 regions (Wiley 1993).

We conclude, instead, that the SV40-MLP contains several independent IBP-s-binding sites. Both competition gel mobility-shift assays (Fig. 4) and competition footprint analyses (Wiley 1993) indicate that IBP-s binds with high affinity to the -5 and +55 region sites. The weaker protection over the +5 and +30 region sites could be the result of a minor contaminant in the purified IBP-s samples. However, we consider it much more likely that these latter protected regions contain additional independent lower-affinity IBP-s sites: (1) The +5 and +30 regions show sequence similarity to the highaffinity IBP-s-binding sequence $5^{\prime}$-AGGTCA-3' (Fig. 4C); (2) a 333- nucleotide $C \rightarrow T$ point mutant exhibits strong protection from DNase I cleavage by IBP-s over its +5 region (data not shown); (3) the +30 region oligonucleotide competes for binding of IBP-s $\sim 10$-fold better than does the pm322C -5 region oligonucleotide (Fig. 4$)_{;}$and (4) the pm324C -5 region oligonucleotide inhibits IBP-smediated protection from DNase I cleavage over the +5 and +30 regions of the wild-type SV40-MLP at much lower concentrations than does the pm322C -5 region oligonucleotide (data not shown).

Why might a promoter contain several sites rather than simply one site for binding of a repressor? Possibilities include the following: (1) to ensure that at least one repressor-binding site is occupied even when the repressor/binding site ratio in the cell is fairly low; (2) to ensure nonleakiness of expression in the repressed state; and (3) to inhibit elongation as well as initiation of transcription.

Also noteworthy is the fact that the highest-affinity IBP-s-binding sites found are similar to 5'-AGGTCA-3'. This sequence is identical to the consensus half-site sequence recognized by many members of the steroid-thy. roid hormone receptor superfamily (Evans 1988). This superfamily contains members that can act as activators or repressors of transcription depending on the context of their binding sites within a promoter (for review, see Gronemeyer 1992) and the presence or absence of appropriate ligands (Fondell et al. 1993). The consensus-binding site sequence, taken together with the partial amino acid sequence and results with the COUP-TF antisera and clones, provide strong evidence that at least one and, quite probably, all three major protein components of IBP-s are members of this superfamily. This finding suggests simple, direct molecular mechanisms by which signal transduction molecules of a host organism's endocrine system might modulate expression of the late promoter of SV40 and other viruses containing binding site sequences for other members of the steroid-thyroid hormone receptor superfamily [e.g., adenoviruses (Fig. 4), BK virus (S.R. Wiley, unpubl.)]. Thus, hormones may significantly affect the expression of DNA viruses as well as retroviruses (e.g., Payvar et al. 1983) and lentiviruses (e.g., Fondell et al. 1993).

\section{Activities of IBP-S}

Data presented here indicate that IBP-s represses transcription of the SV40-MLP in a sequence-specific manner both in vitro (Figs. 5-7) and in vivo (Fig. 8) when the IBP-s-binding site/IBP-s ratio is low but not when this ratio is high. Binding of IBP-s to its two highest affinity sites reduces expression of the SV40-MLP by $\geqslant 90 \%$ (Figs. 6 and 8). The total repression at early times is probably significantly greater than this value because (1) binding of IBP-s to its +5 and +30 sites could still occur in these experiments, and $\{2 \mid$ the IBP-s-binding site/IBP-s ratio in these experiments was much higher than it is in vivo before the onset of SV40 DNA replication at $\sim 12 \mathrm{hr}$ after transfection (Hertz 1986). Using T-antigen-minus, ori-minus variants of SV40 in which the VPI-coding region has been replaced with a sequence encoding luciferase, we observe 50-fold more luciferase in cells transfected with the pm322C mutant than in ones transfected with wild-type SV40 (F. Zuo, unpubl.). Therefore, IBP-s represses expression of the SV40-MLP at early times in infection to a minimum of $1 / 50$ that of a promoter lacking the -5 region IBP-s-binding site. Given the presence of multiple IBP-s-binding sites, the actual repression is probably significantly greater than this value.

The Ad-MLP contains an IBP-s-binding site at approximately -65 (Fig. 4B). This site is overlapping, but not coincident with the biologically important E-box at -60 whose sequence is $5^{\prime}$-CACGTG-3'. This E-box binds numerous transcriptional activator proteins, including USF/MLTF /Carthew et al. 1985; Sawadago and Roeder 1985), MyoD, and c-Myc (Beckmann and Kadesch 1991 and references cited therein). However, it is not yet clear whether IBP-s functions as an activator or repressor of the Ad-MLP.

The partial amino acid sequence, molecular mass, and DNA-binding site sequence specificity indicate that the $55-\mathrm{kD}$ protein of IBP-s either is or is closely related to hERR 1, a member of the steroid-thyroid hormone receptor superfamily for which a ligand has not been found. Also, an antiserum to COUP-TF, a closely related protein, cross-reacts with the purified IBP-s sample as assayed by a Western blot. COUP-TF can function as a repressor of transcription from some promoters (Wang et al. 1991 and references therein), including the SV40MLP (F. Zuo, unpubl.). Thus, it is likely that the repression by IBP-s of transcription from the SV40-MLP in vitro was not the result of contaminants, cleavage of the activation domains of the proteins, denaturation, or other damage to the proteins that may have occurred during purification. The genetic in vivo data (Fig. 8) are also consistent with this conclusion.

\section{Role of IBP-s in SV4O early-to-late switch}

A long-standing question in the field of SV40 gene expression has been the mechanism of the replication-dependent component of the early-to-late switch. One hy- 
pothesis is that replication of the template alters its structure (e.g., chromatin) or location within the nucleus such that transcription of the late promoter can then occur (e.g., Tack and Beard 1985). Another hypothesis is that one or more cellular factors specifically represses transcription of the late promoter at early times, but this repression is relieved at late times by displacement, inactivation, or titration of the repressor (e.g., Alwine and Picardi 1986). The data presented here provide strong support for the titration hypothesis. Because our purified IBP-s was obtained from HeLa cell nuclear extracts, it is noteworthy that transfection of the IBP-s mutations into HeLa cells yielded similar results to those obtained in CV-1PD cells (Fig. 8), except that the accumulation of viral DNA occurred more slowly and the overproduction of late RNA by the mutants continued until later times after transfection (data not shown). We speculate that the replication dependence of the early-to-late shift in the expression of other DNA viruses may also occur by titration of cellular repressors of their late promoters. Consistent with this hypothesis is the presence of IBP-sbinding site sequences in the late promoters of adenovirus type 2 (Fig. 4) and BK virus (S.R. Wiley, unpubl.).

Data presented here (Figs. 6 and 7) indicate that SV40 large T-antigen plays a role in the relief of IBP-s-mediated repression of the late promoter by its central contributions to viral DNA replication (for review, see Boroweic et al. 1990). However, SV40 T-antigen may also contribute directly or indirectly to derepression by other mechanisms as well, such as enabling transcription factors to outcompete IBP-s for stable binding to the promoter and/or inactivating or altering the activity of IBP-s. In addition, other factors or mechanisms may be responsible for yet additional components of the replication-dependent part of the switch, that is, an as-yet-unidentified factor may repress the late promoter at early times by interaction with the 21 -bp repeats of the control region (Alwine and Picardi 1986).

\section{Materials and Methods}

\section{Plasmids and oligonucleotides}

All plasmid DNAs were constructed by standard recombinant DNA techniques (Sambrook et al. 1989). Plasmid pSVL200, used to make probes for DNase I protection analyses, contains SV40 nucleotides $5171-128$ plus nucleotides $201-433$ in place of the HindIII-ScaI region of the polylinker in pSP72 (Promega). The pseudo-wild-type SV40 used in all in vivo experiments was pSV1773, a derivative of pSVS [cloned SV40 strain WT830 (Fromm and Berg 1982)/ lacking SV40 nucleotides 1629-1635, inclusive (Good et al. 1988); the presence of this frameshift mutation prevents the synthesis of the major capsid protein VP1, thereby eliminating potential complications from the packaging of viral templates into virions during in vivo experiments. Plasmids pSV4508(pm322C) and pSV4515(pm324C) are derivatives of pSV1773 containing a point mutation at nucleotide 322 of $\mathrm{G} \rightarrow \mathrm{C}$ and at nucleotide 324 of $\mathrm{T} \rightarrow \mathrm{C}$, respectively; their construction will be described elsewhere (R.J. Kraus, E.E. Murray, S.R. Wiley, N.M. Zink, K. Loritz, and J.E. Mertz, in prep.). Plasmid pSVLS26 contains a substitution of linker DNA $\left\{5^{\prime}\right.$-CGAGATCTCG-3' $\}$ for SV40 nucleotides 378387 (5'-GTAGGTCATG-3') (Ayer and Dynan 1988). Plasmid pSV4534(LS26) was constructed by crossing the linker-scanner mutation of pSVLS26 into our pseudo-wild-type pSV1773 by their NaeI and PpuMI sites. The double mutant plasmid pSV4535(pm322C $\times$ LS26) was constructed likewise by crossing the pSVLS26 mutation into pSV4508(pm322C).

Synthetic oligonucleotides were made by the University of Wisconsin Biotechnology Center (Madison).

\section{Purification of IBP-S}

Method 1 HeLa S-3 cells were grown in suspension culture in Joklik's media plus $5 \%$ calf serum, harvested at $3 \times 10^{5}$ to $5 \times 10^{5} \mathrm{cells} / \mathrm{ml}$, and stored at $-70^{\circ} \mathrm{C}$ at $\sim 1.0 \mathrm{gram}$ of cells $/ \mathrm{ml}$ in $5 \mathrm{mM} \mathrm{KH}_{2} \mathrm{PO}_{4}, 25 \mathrm{~mm} \mathrm{KOH}, 30 \mathrm{~mm} \mathrm{NaCl}, 0.5 \mathrm{~mm} \mathrm{MgCl}_{2}, 20$ $\mathrm{mm}$ lactate, $5 \mathrm{~mm}$ glucose, $0.2 \mathrm{~mm}$ sorbitol, and $10 \%$ DMSO. All subsequent steps were performed at $4^{\circ} \mathrm{C}$ unless indicated otherwise.

Nuclear extracts were prepared essentially as described by Dignam and Roeder (Dignam et al. 1983) from 180 to 200 grams of packed cells /corresponding to cells from $\sim 180$ to 200 liters of suspension culture). Extracts were dialyzed into buffer $\mathrm{B}$ [50 $\mathrm{mm}$ HEPES (pH 7.9), $12.5 \mathrm{~mm} \mathrm{MgCl}_{2}, 1.0 \mathrm{~mm}$ EDTA, 17\% glycerol, $0.1 \mathrm{M} \mathrm{KCl}, 1.0 \mathrm{~mm}$ DTT, and $0.5 \mathrm{~mm}$ phenylmethylsulfonyl fluoride (PMSF)], and passed through an 80-ml DEAE-cellulose column (Whatman) also equilibrated in buffer B minus PMSF. The flowthrough was loaded onto a $100-\mathrm{ml}$ heparin-Sepharose column equilibrated in buffer A [50 mM HEPES (pH 7.4), $6 \mathrm{~mm}$ $\mathrm{MgCl}_{2}, 0.2 \mathrm{~mm}$ EDTA, 20\% glycerol, $0.5 \mathrm{~mm}$ DTT, $100 \mathrm{~mm}$ $\mathrm{KCl}$ ]. IBP-s activity was assayed here and in subsequent purification steps by a DNase I protection assay (see below) and was eluted in a $325-750 \mathrm{~mm} \mathrm{KCl}$ step in buffer $\mathrm{A}$. After dialysis into buffer $\mathrm{A}(\mathrm{pH} 7.0)$ with $50 \mathrm{~mm} \mathrm{KCl}$, this material was applied to a Mono-S HR 5/5 column (Pharmacia). The proteins were fractionated by elution with a $10-\mathrm{ml}, 50-750 \mathrm{~mm} \mathrm{KCl}$ gradient in buffer $\mathrm{A}$. The resulting fractions were adjusted to $50 \%$ glycerol and stored at $-20^{\circ} \mathrm{C}$. Those fractions exhibiting peak IBP-s activity were adjusted to buffer $\mathrm{A}, 100 \mathrm{~mm} \mathrm{KCl}$, and were applied to a "nonspecific sequence" oligonucleotide column prepared as described by Kadonaga and Tjian (1986) with CnBr-activated Sepharose (Pharmacia) and annealed, ligated synthetic oligonucleotides 5'-GCTGCGCCGGCTGTCACGCCAG-3' and 5'AGCCTGGCGTGACAGCCGGCCGC- $3^{\prime}$. The protein containing IBP-s activity flowed through in buffer $A$ and was applied to an SV40 major late initiation site oligonucleotide affinity column (2-ml bed volume) containing the oligonucleotides 5'-CAGAGGTTATTTCAGGC-3' and 5-'CTGGCCTGAAATAACCT -3 '. Fractions eluting during a $250-1000 \mathrm{~mm}$ $\mathrm{KCl}$ gradient in buffer A were collected. Those fractions containing the peak IBP-s activity $(350-450 \mathrm{~mm} \mathrm{KCl})$ were adjusted to $50 \%$ glycerol and stored at $-70^{\circ} \mathrm{C}$.

Method 2 In later experiments (Figs. 2-8) the purification protocol was modified as follows: The Mono-S column and nonspecific oligonucleotide-affinity columns were eliminated, and the sequence of the specific oligonucleotide column was changed at SV40 nucleotide 324 from $\mathrm{T} \rightarrow \mathrm{C}$ to produce a higher affinity IBP-s-binding site (see Fig. 4). Material from the heparin-Sepharose step was dialyzed into buffer $\mathrm{A}(\mathrm{pH} 7.4)$ and loaded onto the specific oligonucleotide column $(2-\mathrm{ml}$ bed volume) in the presence of $2 \mathrm{mg} / 50-\mathrm{ml}$ sample volume of polyld(I$\mathrm{C} \mid] /$ poly[d(I-C)]. Peak fractions were diluted to $200 \mathrm{mM} \mathrm{KCl}$ and applied to the specific oligonucleotide column $(150 \mu)$ bed volume) in the presence of $120 \mu \mathrm{g}$ of poly[d(I-C)]/poly[d(I-C)]. The 
latter column was washed with buffer A, $250 \mathrm{mM} \mathrm{KCl}$. The IBP-s activity was stepped off the column in $400 \mu$ l of buffer A, $650 \mathrm{mM} \mathrm{KCl}$, adjusted to $50 \%$ glycerol, and stored at $-70^{\circ} \mathrm{C}$.

\section{IBP-S SDS-PAGE assays}

Proteins were precipitated according to Wessel and Flügge (1984), resolved by standard Laemmli SDS-PAGE (Laemmli $1970)$, and visualized by silver staining according to Heukeshoven and Dernick (1985). In Figure 3, gel slices from the native gel were equilibrated in Laemmli stacking buffer at $4^{\circ} \mathrm{C}$ for 15 min, placed in a $1.5-\mathrm{mm}$-thick, $12 \%$ Laemmli SDS gel with a 7-cm-long stacking layer (Laemmli 1970), and overlaid with SDS loading buffer before electrophoresis. The sample for the load lane was precipitated before electrophoresis according to Wessel and Flügge (1984).

\section{IBP-s protection assays}

Nontemplate strand probe was prepared by cutting pSVL200 with EcoRI, end-labeling with $\left[\alpha{ }^{-32} \mathrm{P}\right] \mathrm{ATP}$ and the Klenow fragment of DNA polymerase I, cutting with HindIII, and purifying by PAGE. Template strand was prepared likewise, but the restriction enzymes were used in reverse order. Probe and protein samples were combined in $20 \mu \mathrm{l}$ reaction buffer [10\% PEG-8000 (Sigma), 80-100 mM KCl, $6 \mathrm{~mm} \mathrm{MgCl} 2,20 \mathrm{~mm}$ HEPES (pH 7.6)] and incubated on ice for $5 \mathrm{~min}$, at room temperature for $15 \mathrm{~min}$, and at room temperature with DNase I $0.1-0.3$ units; Pharmacia) for $1 \mathrm{~min}$ before the addition of $6 \mu$ l of stop buffer $(0.25 \mathrm{M}$ EDTA and $1 \%$ SDS). Before IBP-s sequence-specific affinity chromatography, reactions included $0.25 \mu \mathrm{g}$ of poly[d(I-C)]/ poly[d(I-C)]. Nonspecific competitor nucleic acid was not necessary afterwards. MPE reactions were performed according to Hertzberg (Hertzberg and Dervan 1984). Subsequent to cleavage, samples were extracted with phenol-chloroform, ethanol precipitated, and resolved by electrophoresis in $6 \%$ polyacrylamide gels containing $8 \mathrm{M}$ urea.

\section{IBP-s gel mobility-shift assays}

The probes used were double-stranded oligonucleotide DNA fragments of SV40 nucleotides 281-366 of the DNAs indicated. Competition assays were performed using the pm324C mutant as probe, as the initiator region of wild-type SV40-MLP does not contain IBP-s-binding sites of sufficient affinity for use as a probe (data not shown). Probes were prepared by PCR with synthetic oligonucleotide primers corresponding to SV40 nucleotides 281-296 and 366-351, followed by gel purification and end-labeling with $\left[\gamma^{32} \mathrm{P}\right] \mathrm{ATP}$ and kinase. Reaction mixtures 120 $\mu$ l) contained $0.3 \mathrm{ng}$ of IBP-s and $0.4 \mathrm{ng}$ of probe mixed in $20 \mathrm{~mm}$ HEPES (pH 7.9), 2 mM spermidine, 0.1 mM EDTA, $0.025 \%$ NP40 (Sigma), $5 \%$ glycerol, $0.5 \mathrm{~mm}$ DTT, and $2 \mathrm{~mm} \mathrm{MgCl}_{2}$. They were incubated at $4^{\circ} \mathrm{C}$ for $5 \mathrm{~min}$ and at room temperature for 15 min before electrophoresis at $4^{\circ} \mathrm{C}$ in native gels containing $4 \%$ acrylamide, $0.04 \%$ bis-acrylamide, $0.025 \%$ NP- 40 , and standard Tris-glycine buffer. The gels shown in Figure 4 were transferred to Whatman paper and dried before autoradiography.

\section{Cell-free transcription assay}

Nuclear extracts were prepared from exponentially growing suspension cultures of HeLa cells $\left(3 \times 10^{5}\right.$ to $5 \times 10^{5}$ cells $\left./ \mathrm{ml}\right)$ essentially as described by Dignam et al. (1983), except extracts (18-20 $\mathrm{mg}$ protein $/ \mathrm{ml}$ ) were dialyzed into buffer A containing 1 $\mathrm{mM}$ DDT and $0.5 \mathrm{~mm}$ PMSF and stored frozen at $-70^{\circ} \mathrm{C}$ until used. Transcription reaction mixtures $(50 \mu 1$ final volume) con- tained $0.5 \mu \mathrm{g}$ of circular plasmid DNA unless indicated otherwise, $25 \mathrm{~mm}$ HEPES ( $\mathrm{pH} 7.4$ ), $6.0 \mathrm{mM} \mathrm{MgCl}_{2}, 1.0 \mathrm{~mm}$ DTT, 0.12 $\mathrm{mM}$ EDTA, $12 \%$ glycerol, $60 \mathrm{mM} \mathrm{KCl}, 80 \mathrm{mM}$ potassium glutamate, and $16 \mu \mathrm{l}$ of HeLa nuclear extract. The reactions were initiated by the addition of nucleoside triphosphates to $600 \mu \mathrm{M}$ each of GTP, CTP, UTP, and $200 \mu \mathrm{M}$ of ATP. After incubation for $30 \mathrm{~min}$ at $26^{\circ} \mathrm{C}$, the reactions were divided in two equal parts. One was terminated with 3 volumes of stop buffer $[0.1 \mathrm{M}$ sodium acetate $(\mathrm{pH} 5.2), 0.4 \%$ SDS, $300 \mu \mathrm{g} / \mathrm{ml}$ of carrier tRNA, $1.0 \mathrm{mM}$ EDTA] and analyzed for SV40 early RNA as an internal control. The other was terminated with the same buffer, but containing $400 \mu \mathrm{g} / \mathrm{ml}$ of poly[d(I-C)]/poly[d[I-C)] as carrier and was analyzed for SV40 late RNA. The nucleic acids were extracted with phenol-chloroform-isoamyl alcohol $(25: 24: 1)$, and this phase was back-extracted with the appropriate stop buffer. The pooled extracts were precipitated with $600 \mu \mathrm{l}$ of absolute ethanol and washed with ethanol. The structures and relative quantities of the $5^{\prime}$ ends of the SV40 late and early RNAs were analyzed by primer extension analysis as described previously (Good et al. 1988). Synthetic oligonucleotides corresponding to SV40 nucleotides $446-422$ and $5136-5160$ were used as primers for the late and early promoters, respectively.

\section{In vivo transcription assay}

CV-1PD cells and HeLa cells were grown in Dulbecco's modified Eagle medium (DMEM) supplemented with $5 \%$ and $10 \%$ fetal bovine serum, respectively. The cells were transfected with the aid of DEAE-dextran followed by chloroquine as described previously (Good et al. 1988). Viral recombinant DNA $(3.5 \mu \mathrm{g} / 10-\mathrm{cm}$ dish) was excised from the vector sequences and ligated to form monomer circles before transfection. Total cellular RNA was isolated at the times indicated after transfection as described by Good et al. (1988). The relative amounts of steady-state early and late SV40 RNA were determined by quantitative S1 nuclease mapping as described previously (Hertz and Mertz 1986), with end-labeled DNAs similar to those described in Figures 3 and 2, respectively, of Hertz and Mertz (1986) used as probes.

\section{Partial amino acid sequence analysis of IBP-s}

IBP-s was prepared from $250 \mathrm{ml}$ of HeLa cell nuclear extract according to method 2 . This material was precipitated according to Wessel and Flügge (1984) and sent to Kendrick Laboratories (Madison, WI) for blotting onto PVDF membrane. After visualization by staining with Coomassie brilliant blue, the slowest migrating of the three major protein bands (molecular mass $\sim 55 \mathrm{kD}$ / was excised from the membrane and sent to Dr. MaryAnn Gewinowicz at the Protein Chemistry Core Facility at Columbia University (NY) for digestion with endoproteinase Lys$\mathrm{C}$, peptide separation by HPLC, and micropeptide sequence analysis.

\section{Acknowledgments}

We thank Peggy Farnham for HeLa S-3 cells and advice on making transcription extracts from them, Mark Knuth and Alan Poland for advice on protein purification techniques, MaryJo Rosovitz for construction of plasmids pSV4534 and pSV4535, $\mathrm{M}$. Tsai for COUP-TF plasmids and antisera, Nancy Kendrick of Kendrick Laboratories for blotting IBP-s onto PVDF membrane, Mary-Ann Gewinowicz for performing peptide sequence analysis of IBP-s, and members of our laboratory for discussions and helpful comments on the manuscript. We also thank Dick Bur- 
gess, Paul Lambert, and Bill Sugden for helpful comments on this manuscript. This research was supported by U.S. Public Health Service grants CA-07175, CA-09135, and CA-22443 from the National Cancer Institute.

The publication costs of this article were defrayed in part by payment of page charges. This article must therefore be hereby marked "advertisement" in accordance with 18 USC section 1734 solely to indicate this fact.

\section{References}

Alwine, J.C. and J. Picardi. 1986. Activity of simian virus 40 late promoter elements in the absence of large $T$ antigen: Evidence for repression of late gene expression. I. Virol. 60: 400404.

Ayer, D.E. and W.S. Dynan. 1988. Simian virus 40 major late promoter: A novel tripartite structure that includes intragenic sequences. Mol. Cell. Biol. 8: 2021-2033.

- 1990. A downstream-element-binding factor facilitates assembly of a functional preinitiation complex at the simian virus 40 major late promoter. Mol. Cell. Biol. 10: 3635-3645.

Baniahmad, A., C. Steiner, A.C. Köhne, and R. Renkawitz. 1990. Modular structure of a chicken lysozyme silencer: Involvement of an unusual thyroid hormone receptor binding site. Cell 61: 505-514.

Beckmann, H. and T. Kadesch. 1991. The leucine zipper of TFE3 dictates helix-loop-helix dimerization specificity. Genes \& Dev. 5: 1057-1066.

Borowiec, J.A., F.B. Dean, P.A. Bullock, and J. Hurwitz. 1990. Binding and unwinding-How $\mathrm{T}$ antigen engages the SV40 origin of DNA replication. Cell 60: 181-184.

Brady, J., M. Radonovich, M. Vodkin, V. Natarajan, M. Thoren, G. Das, J. Janik, and N.P. Salzman. 1982. Site-specific base substitution and deletion mutations that enhance or suppress transcription of the SV40 major late RNA. Cell 31: 625-633.

Carthew, R.W., L.A. Chodosh, and P.A. Sharp. 1985. An RNA polymerase II transcription factor binds to an upstream element in the adenovirus major late promoter. Cell 43: 439448.

Casaz, P., R. Sundseth, and U. Hansen. 1991. trans activation of the simian virus 40 late promoter by large $T$ antigen requires binding sites for the cellular transcription factor TEF-1. I. Virol. 65: 6535-6543.

Cooney, A.J., S.Y. Tsai, B.W. O'Malley and M.-I. Tsai. 1992. Chicken ovalbumin upstream promoter transcription factor (COUP-TF) dimers bind to different GGTCA response elements, allowing COUP-TF to repress hormonal induction of the vitamin D3, thyroid hormone, and retinoic acid receptors. Mol. Cell. Biol. 12: 4153-4163.

Coulombe, J., L. Berger, D. Smith, R.K. Hehl, and A.G. Wildeman. 1992. Activation of simian virus 40 transcription in vitro by $\mathrm{T}$ antigen. J. Virol. 66: 4591-4596.

Dignam, J.D., R.M. Lebovitz, and R.G. Roeder. 1983. Accurate transcription initiation by RNA polymerase II in a soluble extract from isolated mammalian nuclei. Nucleic Acids Res. 11: 1475-1489.

Evans, R.M. 1988. The steroid and thyroid hormone receptor superfamily. Science 240: 889-895.

Faisst, S. and S. Meyer. 1992. Compilation of vertebrate-encoded transcription factors. Nucleic Acid Res. 20: 3-26.

Fondell, J.D., A.L. Roy, and R.G. Roeder. 1993. Unliganded thyroid hormone receptor inhibits formation of a functional preinitiation complex: Implications for active repression. Genes \& Dev. 7: 1400-1410.
Fromm, M. and P. Berg. 1982. Deletion mapping of DNA regions required for SV40 early region promoter function in vivo. $J$. Mol. Appl. Genet. 1: 457-481.

Gigùere, V., N. Yang, P. Segui, and R.M. Evans 1987. Identification of a new class of steriod hormone receptors. Nature 331: 91-94

Good, P.J., R.C. Welch, W.S. Ryu, and J.E. Mertz. 1988. The late spliced 19S and 16S RNAs of simian virus 40 can be synthesized from a common pool of transcripts. J. Virol. 62: 563571.

Gronemeyer, H. 1992. Control of transcription activation by steroid hormone receptors. FASEB I. 6: 2524-2529.

Gruda, M.C. and J.C. Alwine. 1991. Simian virus 40 (SV40) $\mathrm{T}$-antigen transcriptional activation mediated through the Oct/SPH region of the SV40 late promoter. I. Virol. 65: 3553-3558.

Hay, N., H. Skolnik-David, and Y. Aloni. 1982. Attenuation in the control of SV40 gene expression. Cell 29: 183-193.

Hertz, G.Z. 1986. "Comparison of the DNA sequence of simian virus 40 required for the synthesis of early RNA, late RNA, and viral DNA." Ph.D. thesis, University of Wisconsin, Madison, WI.

Hertz, G.Z. and J.E. Mertz. 1986. Bidirectional promoter elements of simian virus 40 are required for efficient replication of the viral DNA. Mol. Cell. Biol. 6: 3513-3522.

Hertzberg R.P. and P.B. Dervan. 1984. Cleavage of DNA with methidiumpropyl-EDTA-iron(II): Reaction conditions and product analyses. Biochemistry 23: 3934-3945.

Heukeshoven, J. and R. Dernick. 1985. Simplified method for silver staining of proteins in polyacrylamide gels and the mechanism of silver staining. Electrophoresis 6: 103-112.

Ing, N.H., J.M. Beekman, S.Y. Tsai, M.-J. Tsai, and B.W. O'Malley. 1992. Members of the steroid hormone receptor superfamily interacts with TFIIB (S300-II) J. Biol. Chem. 267: 17617-17623.

Kadonaga, J.T. and R. Tiian. 1986. Affinity purification of sequence-specific DNA binding proteins. Proc Natl. Acad Sci. 83: 5889-5893.

Laemmli, U.K. 1970. Cleavage of structural proteins during assembly of the head of bacteriophage T4. Nature 227: 680685.

Lazar, M.A., T.J. Berrodin, and H.P. Harding. 1991. Differential DNA binding by monomeric, homodimeric, and potentially heteromeric forms of thyroid hormone receptor. Mol. Cell Biol. 11: 5005-5015.

Payvar, F., D. DeFranco, G.L. Firestone, B. Edgar, O. Wrange, S. Okret, J.- $\AA$. Gustafsson, and K.R. Yamamoto. 1983. Sequence-specific binding of glucocorticoid receptor to MTV DNA at sites within and upstream of the transcribed region. Cell 35: 381-392.

Reed, S.I., G.R. Stark, and I.C. Alwine. 1976. Autoregulation of simian virus 40 gene A by T antigen. Proc. Natl. Acad. Sci. 73: 3083-3087.

Sambrook, J., E.F. Fritsch, and T. Maniatis, eds. 1989. Molecular cloning: A laboratory manual, 2nd ed. Cold Spring Harbor Laboratory Press, Cold Spring Harbor, New York.

Sawadogo, M. and R.G. Roeder. 1985. Interaction of a genespecific transcription factor with the adenovirus major late promoter upstream of the TATA box region. Cell 43: 165175.

Somasekhar, M.B. and J.E. Mertz. 1985. Sequences involved in determining the locations of the 5 ' ends of the late RNAs of simian virus 40. I. Virol. 56: 1002-1013.

Tack, L.C. and P. Beard. 1985. Both trans-acting factors and chromatin structure are involved in the regulation of transcription from the early and late promoters in simian virus 
40 chromosomes. J. Virol. 54: 207-218.

Tjian, R. 1981. T antigen binding and the control of SV40 gene expression. Cell 26: 1-2.

Tooze, J., ed. 1981. Molecular biology of tumor viruses, 2 nd ed. Cold Spring Harbor Laboratory Press, Cold Spring Harbor, New York.

Wang, L., S.Y. Tsai, R.G. Cook, W.G. Beattie, M.-J. Tsai., and B.W. O'Malley. 1989. COUP transcription factor is a member of the steroid receptor superfamily. Nature 340: 163166.

Wang, L., N.H. Ing, Y.T. Tsai, B.W. O'Malley, and M. Tsai. 1991. The COUP-TFs compose a family of functionally related transcription factors. Gene Expression 1: 207-216.

Wessel, D. and U.I. Flügge. 1984. A method for the quantitative recovery of protein in dilute solution in the presence of detergents and lipids. Anal. Biochem. 138: 141-143.

Wildeman, A.G. 1989. Transactivation of both early and late simian virus 40 promoters by large tumor antigen does not require nuclear localization of the protein. Proc. Natl. Acad. Sci. 86: 2123-2127.

Wiley, S.R. 1993. Cellular factors regulating transcription of the simian virus 40 major late promoter. Ph.D. thesis. University of Wisconsin, Madison, WI.

Wiley, S.R., R.J. Kraus, and J.E. Mertz, 1992. Functional binding of the "TATA" box binding component of transcription factor TFIID to the -30 region of TATA-less promoters. Proc. Natl. Acad. Sci. 89: 5814-5818.

Xiao, J.H., I. Davidson, H. Matthes, J.-M. Garnier, and P. Chambon. 1991. Cloning, expression, and transcriptional properties of the human enhancer factor TEF-1. Cell 65: 551-568.

Zawel, L. and Reinberg, D. 1992. Advances in RNA polymerase II transcription. Curr. Opin. Cell Biol. 4: 488-495. 


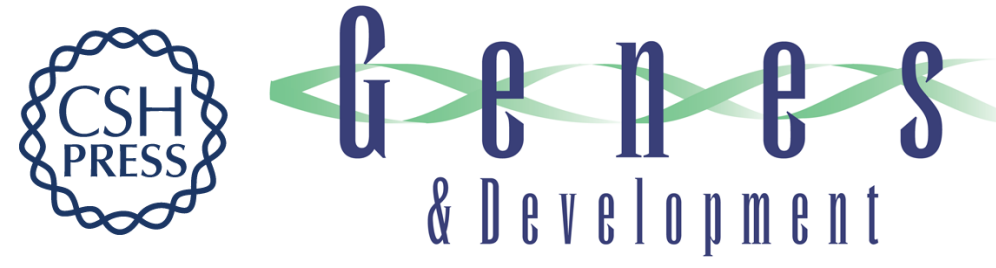

\section{SV40 early-to-late switch involves titration of cellular transcriptional repressors.}

S R Wiley, R J Kraus, F Zuo, et al.

Genes Dev. 1993, 7:

Access the most recent version at doi:10.1101/gad.7.11.2206

References This article cites 41 articles, 19 of which can be accessed free at:

http://genesdev.cshlp.org/content/7/11/2206.full.html\#ref-list-1

License

Email Alerting

Service

Receive free email alerts when new articles cite this article - sign up in the box at the top right corner of the article or click here.

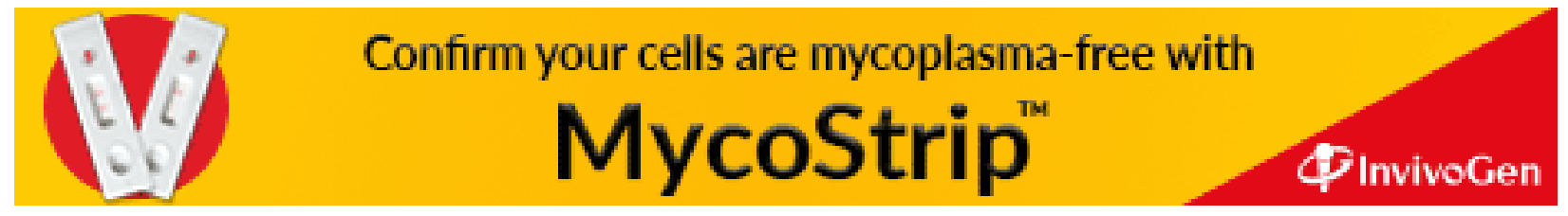

